IZA DP No. 2264

The J ack-of-All-Trades Entrepreneur: Innate Talent or Acquired Skill?

Olmo Silva

August 2006 


\title{
The Jack-of-All-Trades Entrepreneur: Innate Talent or Acquired Skill?
}

\author{
Olmo Silva \\ CEP, London School of Economics \\ and IZA Bonn
}

Discussion Paper No. 2264

August 2006

\author{
IZA \\ P.O. Box 7240 \\ 53072 Bonn \\ Germany \\ Phone: +49-228-3894-0 \\ Fax: +49-228-3894-180 \\ Email: iza@iza.org
}

Any opinions expressed here are those of the author(s) and not those of the institute. Research disseminated by IZA may include views on policy, but the institute itself takes no institutional policy positions.

The Institute for the Study of Labor (IZA) in Bonn is a local and virtual international research center and a place of communication between science, politics and business. IZA is an independent nonprofit company supported by Deutsche Post World Net. The center is associated with the University of Bonn and offers a stimulating research environment through its research networks, research support, and visitors and doctoral programs. IZA engages in (i) original and internationally competitive research in all fields of labor economics, (ii) development of policy concepts, and (iii) dissemination of research results and concepts to the interested public.

IZA Discussion Papers often represent preliminary work and are circulated to encourage discussion. Citation of such a paper should account for its provisional character. A revised version may be available directly from the author. 
IZA Discussion Paper No. 2264

August 2006

\section{ABSTRACT \\ The Jack-of-All-Trades Entrepreneur: Innate Talent or Acquired Skill?*}

Cross-sectional tests of the Jack-of-All-Trades theory of entrepreneurship invariably conclude that accumulation of balanced skill-mix across different fields of expertise stimulates entrepreneurship. Yet, none of these considers individual unobservable characteristics which may simultaneously determine skill accumulation and occupational choice. Using panel techniques to control for this, I show that gathering expertise across various subjects does not increase the chances of becoming entrepreneur.

JEL Classification: $\quad$ M13, J23, J24

Keywords: entrepreneurship, occupational choice, skills

Corresponding author:

Olmo Silva

Centre for Economic Performance

London School of Economics

Houghton Street

London WC2A 2AE

United Kingdom

E-mail: o.silva@Ise.ac.uk

* Comments from friends, colleagues and participants at seminars and conferences too numerous to be listed are fully acknowledged. I am responsible for any errors or omissions. 
Word Count: 1898.

(Including body text, footnotes, references, table captions and table notes; excluding title page)

\section{1-Introduction}

Since Schumpeter (1911), entrepreneurs are believed to be a significant determinant of one country's economic performance, particularly with respect to innovation processes and job creation (see Acs and Audretsch, 2003 for a review). Despite this prominent role, the study of entrepreneurship lacks of consensus on the most crucial question: what makes an entrepreneur?

A recent theory formalized in Lazear (2005) and based on balanced skill-mix across fields of expertise has gained some consensus. This posits that an individual who is 'innately' well versed in a variety of fields, i.e. a Jack-of-All-Trades (JAT), has a high probability of becoming entrepreneur. The idea is that, as entrepreneurs need to manage different people and tasks, they must be sufficiently well versed in a variety of fields. The theory also predicts that would-be entrepreneurs should have human capital investment strategies balanced across different competences, highlighting a link between individual innate attitudes and the choice to acquire expertise across various fields.

Cross-sectional evidence in Lazear (2004), (2005) shows that measures capturing individuals' breadth of experience across various fields affect their probability of becoming entrepreneur, providing general support for a JAT view of entrepreneurship. Consistent evidence is given in Wagner (2003a), (2003b) on German data, Baumol (2004) on US and international trends, and Astebro (2005) on Canadian data. Researchers have then come to the conclusion that accumulation of a balanced skill-mix causally stimulates entrepreneurship.

However, cross-sectional tests of the JAT theory cannot control for individual unobservable characteristics which may simultaneously affect skill accumulation and 
occupational choice: as implied by Lazear's theory, individuals innately well versed in a variety of fields have incentives to accumulate more balanced skill-mix. Cross-sectional studies are therefore ultimately silent on whether acquiring a balanced expertise really stimulates entrepreneurship.

In this paper, I use panel techniques to analyze a longitudinal, Italian representative dataset and shed light on this issue while controlling for individual unobservables. I show that, when cross-sectional techniques are used, a JAT proxy measuring individuals' breadth of experience across subjects is positively linked to entrepreneurial choice. Yet, when panel techniques are used, I find that changes in the spread of knowledge across different fields do not increase the probability of becoming entrepreneur. I interpret this as the causal effect of acquiring a more balanced skill-mix on individuals' occupational choice and conclude that the positive cross-sectional findings are driven by unobservables.

The next Section describes the data, while Section 3 presents regressions results and gives some concluding remarks.

\section{2-Data}

This empirical investigation is based on Italian data contained in ILFI Survey (Longitudinal Survey of Italian Families; ILFI, 1997) and providing a representative picture of the Italian working population. The data was collected to obtain a detailed description of labour market transitions and educational attainments of Italian households through the analysis of individual life-histories; it is organized as a job history panel where sampled individuals have one row of data for each experienced occupational spell. 
I classify as entrepreneurs self-employed individuals with or without employees, and managing partners of firms/companies. Individuals working for family businesses are instead excluded from my definition because these jobs often involve little entrepreneurial tasks (such as decision making and innovative activities); results are robust to inclusion of this category. All salaried employed individuals are classified as dependent workers.

Following Lazear (2005), I construct the next JAT skill-mix proxy capturing individuals' breadth of experience across different fields: the total number of roles covered during their job careers before current employment spell.

This is derived from specific information about roles held by individuals in each job. Roles can change between jobs, as well as during the same job spell, or remain constant across different spells; for example, an individual's total number of roles would equal three if she had three jobs, always performing different tasks; or two jobs, with one role in the first, and two different roles during the second. Type of activities performed goes from top managerial tasks to basic blue collars roles, with no decisional requirements, including a wide range of white collar activities. Considering there seems to be enough variation in the skill requirements of different roles, this variable is a good proxy for the breadth of expertise cumulated by individuals before current job spell.

The set of controls used in the regression analysis include information about individuals' familial status, educational attainments, average job tenure before current job spell and unemployment events. However, no information about financial assets is available; instead, we include a wide set of family background information, including a dummy for father entrepreneur when the individual was 14 year-old. 
Table 1 presents descriptive statistics. Sampled individuals are heads of household aged between 18 and 60 who have finished full-time education and were been born after 1936 (to reduce 'recall bias'). The dataset counts about 5200 job spells with entrepreneurial occupations representing $20 \%$ of the total. Importantly, only information from the second job spell onwards is used because previous average job tenure cannot be properly defined for the first job; since I want to build on the analysis in Lazear (2003), (2005) which includes this control, this is the relevant sample for the analysis. ${ }^{1}$

As found by previous research, entrepreneurs tend to be older, more frequently married and have more children than dependent workers; also, entrepreneurs' fathers are more likely to be entrepreneurs themselves when the individuals were 14 year-old. Finally, descriptive statistics show that entrepreneurs have higher mean values for the JAT proxy, suggesting that they tend to be experienced in a wider variety of fields. ${ }^{2,3}$

\section{3-Regression Analysis}

The regression analysis in this Section models the probability of being entrepreneur as a function of the JAT skill-mix proxy, controlling for individual characteristics. The main issue investigated is whether gathering expertise across different fields 'causally' increases individuals' chances of becoming entrepreneur.

Since individual unobservable characteristics may simultaneously determine skill accumulation strategies and occupational choice, cross-sectional analysis can hardly provide a meaningful answer to this question. To shed light on this issue, I model the longitudinal

\footnotetext{
${ }^{1}$ Results for the entire sample, treating the first tenure spell as zero, did not prove different.

${ }^{2}$ The difference is significant with a t-test value of 5.86 .

${ }^{3}$ The variable varies between 1 and 8 ; the top decile and quintile of the distribution are 3 and 5 respectively.
} 
dimension of the data using fixed effect panel techniques to control for individual unobserved characteristics that are constant over time.

Columns 1 and 2 of Table 2 present results of cross-sectional regressions fitting linear probability models. ${ }^{4}$ Column 1 replicates Lazear's results including educational dummies, age, gender, previous average job tenure, Italian nationality and number of previously held roles; Column 2 scrutinizes the findings by adding a battery of controls (including Region and Sector dummies and family background information, such as father entrepreneur when the individual was 14).

The positive and large coefficient on the total number of roles suggests that a JAT attitude has sizable effect on the probability of being an entrepreneur: one additional role increases this probability by 2.5 percentage points, or about $15 \%$ (given sample frequency of entrepreneurs).

Two different interpretations can be given to this result (both consistent with Lazear's theory). First: individuals innately talented in many fields can perform a large number of tasks; the JAT proxy merely captures inborn abilities and the documented correlation reflects person specific effects. Alternatively: would-be entrepreneurs intentionally 'invest' in more heterogeneous role-mix to acquire a broad set of skills; this increases their chances of running a business. The remainder of this Section tries to shed light on this issue.

Given that my JAT proxy is a time varying individual characteristic, standard fixed effect techniques can be used to model the data controlling for time-fixed individual unobservables. This allows identifying how changes in the number of roles held affect subsequent move into entrepreneurship, providing insights on whether acquiring a balanced skill-mix 'causally'

\footnotetext{
${ }^{4}$ Logit and probit alternatives were also used, giving similar conclusions.
} 
increases the chances of becoming entrepreneur. Findings are presented in Table 2, Columns 3 and 4 (controls as Columns 1 and 2 respectively). ${ }^{5}$

Once unobservables are purged out of the regressions, I find that acquiring a wider set of skills does not increase the probability of an entrepreneurial spell; the coefficient attached to the JAT proxy is negative, although insignificant. This clashes with previous findings and suggests that unobservables may be driving cross-sectional results. ${ }^{6}$

Next, the model in Column 1 is re-estimated including actual number of roles and maximum number of roles covered by individuals over their entire work history. ${ }^{7}$ If performing different roles enhances the chances of becoming entrepreneur, actual roles should be relevant to the entrepreneurial choice; if instead, a JAT attitude only matters as an innate attribute, the maximum number of roles should be more salient as it proxies for individuals' overall entrepreneurial ability. Results are reported in Columns 5. I find that the effect of actual number of roles is smaller than previously found and completely insignificant; the coefficient attached to the maximum number of roles instead is large and statistically significant.

All in all, this analysis suggests that if a JAT attitude matters for entrepreneurship, it does so as an innate ability. Previous claims, on the 'causal' effect of acquiring a balanced skill-mix on the probability of becoming entrepreneur, should be more cautiously interpreted.

\footnotetext{
${ }^{5}$ Observations drop because only individuals with more than one job spell are retained; results are not driven by changes in the sample.

${ }^{6}$ Also, a Breush-Pagan test strongly rejects the null of no unobserved heterogeneity for both specifications and Hausman tests on fixed effects specifications reject the consistency of random effect estimators. This casts further doubt on the validity of a 'causal' interpretation of cross-sectional findings.

${ }^{7}$ In this specification, average job tenure is replaced by total years of experience acquired before a given job spell and maximum years of experience before the last work event, to control for life-cycle effect which may affect number of roles covered.
} 


\section{References}

Acs, Z, Audretsch, D (2003), Handbook of Entrepreneurship Research, Kluwer Academics Publishers.

Astebro, T (2005), ‘Does It Pay to Be a Jack-of-All-Trades?’, DRUID Paper, October 2005.

Baumol, WJ (2004), 'Education for Innovation: Entrepreneurial Breakthroughs vs. Corporate Incremental Improvements’, NBER WP10578.

ILFI (1997), Universities of Trento, Milan Bicocca and Bologna and Istituto Trentino di Cultura, 'Longitudinal Survey of Italian Households, 1997'; Project coordinator: A. Schizzerotto.

Lazear, EP (2004), 'Balanced Skills and Entrepreneurship', American Economic Review, Papers and Proceedings, May 2004.

Lazear, EP (2005), 'Entrepreneurship', Journal of Labor Economics, 23(4).

Schumpeter, J (1911), The Theory of Economic Development, Harvard.

Wagner, J (2003a), 'Testing Lazear's Jack-of-All-Trades View of Entrepreneurship with German Data', Applied Economic Letters, 10.

Wagner, J (2003b), ‘Are Nascent Entrepreneurs Jack-of-All-Trades? A Test of Lazear's Theory of Entrepreneurship Using German Data’, IZA DP911. 
Table 1: Descriptive Statistics

\begin{tabular}{|c|c|c|c|c|c|c|}
\hline & \multicolumn{3}{|c|}{ Dependent Worker } & \multicolumn{3}{|c|}{ Entrepreneur } \\
\hline & N.of Obs. & Mean & St.Dev & N.of Obs. & Mean & St.Dev \\
\hline Tot. N. Roles & 4188 & 1.56 & 0.92 & 985 & 1.76 & 1.08 \\
\hline Max.N.Roles & 4188 & 2.09 & 1.27 & 985 & 2.23 & 1.36 \\
\hline \multicolumn{7}{|l|}{ Basic Controls } \\
\hline Age & 4188 & 28.9 & 8.05 & 985 & 31.6 & 8.49 \\
\hline Female & 4188 & 0.11 & 0.31 & 985 & 0.07 & 0.25 \\
\hline Italian & 4188 & 0.99 & 0.10 & 985 & 0.99 & 0.09 \\
\hline No Schooling & 4184 & 0.02 & 0.15 & 985 & 0.01 & 0.10 \\
\hline Primary School & 4184 & 0.23 & 0.42 & 985 & 0.24 & 0.43 \\
\hline Secondary School & 4184 & 0.34 & 0.47 & 985 & 0.37 & 0.48 \\
\hline High School & 4184 & 0.32 & 0.46 & 985 & 0.31 & 0.46 \\
\hline University & 4184 & 0.07 & 0.25 & 985 & 0.05 & 0.23 \\
\hline Post-graduate Degrees & 4184 & 0.02 & 0.13 & 985 & 0.01 & 0.11 \\
\hline Av.Job Tenure (in Years) & 4188 & 3.06 & 2.23 & 985 & 3.92 & 2.56 \\
\hline \multicolumn{7}{|l|}{ Additional Controls } \\
\hline Married & 4188 & 0.48 & 0.49 & 985 & 0.63 & 0.48 \\
\hline N.Children & 4188 & 0.64 & 0.94 & 985 & 0.86 & 1.02 \\
\hline Out Orig.Family & 4171 & 0.52 & 0.50 & 980 & 0.58 & 0.49 \\
\hline N.Siblings & 4188 & 2.28 & 2.01 & 985 & 2.27 & 1.96 \\
\hline Father Entrepreneur & 4031 & 0.30 & 0.46 & 939 & 0.40 & 0.49 \\
\hline N.Years Unemployment & 4188 & 0.90 & 1.17 & 985 & 0.32 & 1.13 \\
\hline
\end{tabular}

Note: Variables refer to individual status at the beginning of an employment spell. Tot.N.Roles is total number of roles held by an individual before the considered job spell. Max.N.Roles is total number of roles covered over the entire work history. Out Orig. Family indicates whether the individual is not living with the original family. Father Entrepreneur indicates whether father was entrepreneur when the individual was 14 . 
Table 2: Regressions Results

\begin{tabular}{|c|c|c|c|c|c|}
\hline & $\begin{array}{l}\text { (1) Linear } \\
\text { Probability }\end{array}$ & $\begin{array}{l}\text { (2) Linear } \\
\text { Probability }\end{array}$ & $\begin{array}{l}\text { (3) Fixed } \\
\text { Effect }\end{array}$ & $\begin{array}{l}\text { (4) Fixed } \\
\text { Effect }\end{array}$ & $\begin{array}{l}\text { (1) Max. and } \\
\text { Actual Roles }\end{array}$ \\
\hline Tot.N.Roles & $\begin{array}{l}0.027 * * \\
(0.007)\end{array}$ & $\begin{array}{l}0.025 * * \\
(0.007)\end{array}$ & $\begin{array}{l}-0.004 \\
(0.011)\end{array}$ & $\begin{array}{l}-0.009 \\
(0.012)\end{array}$ & $\begin{array}{c}0.036 \\
(0.066)\end{array}$ \\
\hline Max.N.Roles & & & & & $\begin{array}{c}0.123 * * \\
(0.046)\end{array}$ \\
\hline N.of Obs. & 5169 & 4820 & 4313 & 4046 & 4313 \\
\hline Basic Controls & Yes & Yes & Yes & Yes & Yes \\
\hline Additional Controls & No & Yes & No & Yes & No \\
\hline $\begin{array}{l}\text { Region and Sector } \\
\text { Dummies }\end{array}$ & No & Yes & No & Yes & No \\
\hline \multicolumn{6}{|l|}{ Breush-Pagan Test: } \\
\hline Stat.Value: & -- & -- & 174.75 & 95.75 & -- \\
\hline P-Value: & -- & -- & 0.000 & 0.000 & -- \\
\hline \multicolumn{6}{|l|}{ Hausman Test: } \\
\hline Stat.Value: & -- & -- & 25.13 & 70.64 & -- \\
\hline P-Value: & -- & -- & 0.000 & 0.000 & -- \\
\hline
\end{tabular}

Note: The dependent variable is a dummy taking value one for entrepreneurs and zero for dependent workers. Controls in Columns 5 same as in Column 1 but average job tenure is replaced by actual and maximum years of work experience. Robust S.E. in parentheses; $\mathrm{p}<0.01=* *$. 